\title{
複数の振動数成分が同程度に卓越する ランダム水平振動に対する知覚特性に関する研究 CHARACTERISTICS OF PERCEPTION ON RANDOM HORIZONTAL VIBRATION CONTAINING PREDOMINANT FREQUENCY WAVES TO THE SAME DEGREE
}

\author{
石川孝重*, 久木章江**
}

Takashige ISHIKAWA and Akie HISAGI

\begin{abstract}
In this study, we performed an experiment for random vibration containing predominant frequency waves to the same degree. The objective was to investigate the influence of the characteristics of perceptual frequency of the random vibration based on the component of a complex vibration.

Results show that the effects due to the difference of the waveform pattern on random vibration in the range of $30 \%$ to $50 \%$ of the subjects probability of perception have less impact but it's more than that at a $10 \%$ and $90 \%$ rate of probability of perception.
\end{abstract}

\author{
Keywords : Environmental vibration, Random vibration, Predominant frequency, Probability of perception, \\ Threshold, Horizontal vibration \\ 環境振動，ランダム振動，卓越振動数，知覚確率，閾值，水平振動
}

\section{1. はじめに}

ランダム水平振動に対する評価としては国際規格である ISO 26311他があるが, 振動レベルに基づくもので, 建物の振動数を評価 の基本とする建築の設計や評価としては, 馴染みにくく使用が限定 的であり, 現在でも正弦振動を基盤とした居住性能評価指針 2)が広 く使われている。

しかしながら，交通や風によって住宅に実際に生じる振動の波形 は, 複数の振動数成分を含み, 振動数や振幅が時々刻々と変化する。 実環境に生じる振動は風や道路交通, 建設工事など, 発生源などに よって特徴が異なる。複雑な物理特性をもつランダム水平振動の建 築分野における知覚特性に関しては, 塩谷ら 3) の知見があるが, 対 象の振動数が長周期地震動などの振動数が低い範囲におけるもので あり，汎用的な知見を得られていないのが現状である。

そこで本研究では, 戸建て住宅内で実測した車輛や鉄道による水 平振動を用いた被験者実験を実施してきた。4 6) 交通振動などの実 測振動を一例として取り上げながら, 振動数範囲を広げて検討する ことで, ランダム振動としての波形や卓越振動数の違いが知覚に及 ぼす影響を検討した。その結果, 実測データの離散間隔を変化させ た被験者実験から, 振動数成分が顕著に卓越している場合のランダ ム振動の知覚を, FFT 分析による卓越振動数と時系列波形における
加速度最大值で評価できる可能性を見出した。 $\left.{ }^{4}\right)$ 一方, 振動数成分 が複雑に組み合わさった波形の場合はやや異なる傾向が見受けられ， 振動数成分が知覚に及ぼす影響の検討が今後の課題となった。

そこで本論文では, 複数の振動数成分が同程度に卓越する元波形 を増やして行った実験の結果を用い, 複雑な振動数成分がランダム 振動の知覚特性に与える影響について検証する。

また，これまで環境振動に関する評価で基盤とされてきた正弦振 動と比較することでランダム振動の知覚特性を明らかにする。 なお，本論文の一部は，文献5,6)において速報している。

\section{2. 被験者に対する振動台実験の概要}

振動数成分が知覚に及ぼす影響を検討するために，戸建て住宅で 発生した実測振動を元波形として, 波形の種類や振動の入力方法, 継続時間などが異なる実験 $\mathrm{A}, \mathrm{B}$ の 2 種類を実施した。実験 B は振 動数 $0.4 \mathrm{~Hz}$ も実験対象としている。

\section{(1)実験の実施状況}

振動台を用いた被験者実験における居室内の状況を図 1 に示す。 $3 \mathrm{~m} \times 3 \mathrm{~m}$ の加振テーブルの上に天井高さ $3 \mathrm{~m}$ の鋼材製の居室を設置 し，床面にはカーペットを敷いている。壁，空などの内装は住宅に 用いられるものと同様の建材を用いた。 


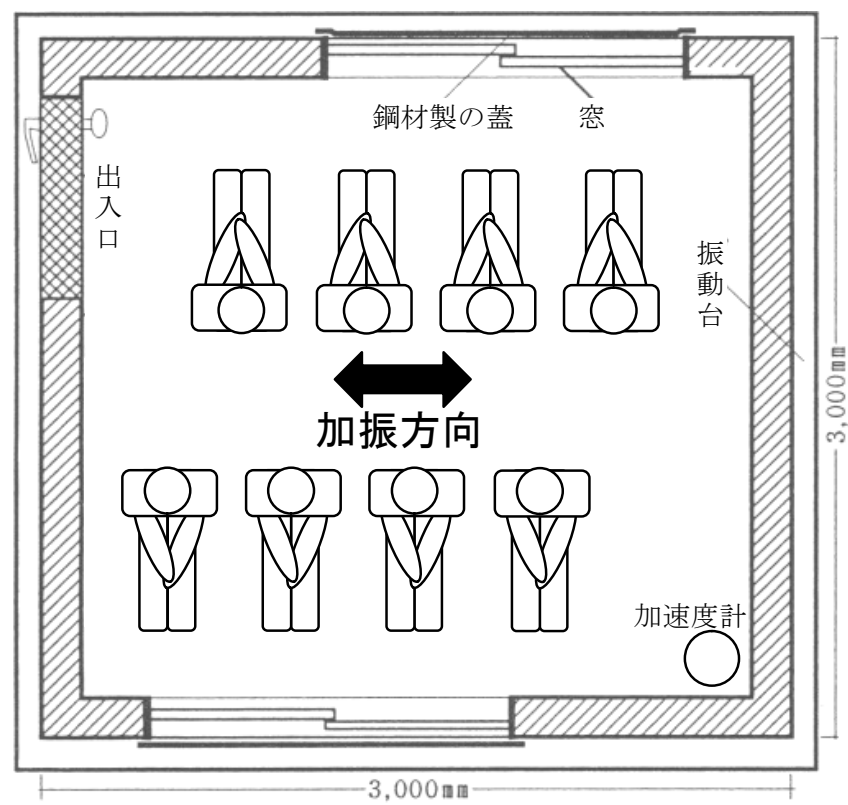

図 1 実験における居室内の状況

また，体感による評価を対象とするため, 体感以外に振動を想起 させる要因となる物の動きや音をできるかぎり排除した状態で実験 を行った。そのため, 居室自体の剛性がきわめて高く, 卓越振動数 $25 \mathrm{~Hz}$ かつ加速度が大きい波形で共振による音が発生する場合があ ったが，実験後に被験者に行ったヒアリングでは，これらの音は加 速度が大きくなってから発生しており, 知覚特性に関わる範疇では 結果に影響していないことを確認している。

居室内では 8 名の被験者が脚をくの字に曲げた状態で床に座り, 知覚の応答に用いるボタンを手に握る。曲げた脚の下で両手でボタ ンを握るように指示し, 他の被験者からボタンへの応答が見えない ように配慮した。被験者に対して実験者が実験の開始を伝えた後,
振動を感じている間このボタンを押し続けるよう事前に指示した。

実験者は, 居室の外で CCD カメラを通して被験者の状況を観察 しながら被験者に対して左右水平方向に振動を入力し，この間の入 力振動をサーボ型加速度計で計測する。入力振動の実測データは, 各被験者のボタンによる知覚応答の電圧とともにデジタルデータレ コーダで収録し，結果の評価に用いた。

本論文では, 先行研究 4)で述べた結果をふまえ, 卓越する振動数 が複数ありそれらが拮抗する, より複雑な振動数特性がランダム振 動の知覚に及ぼす影響の検討を目的としている。そこで，元にした 実測波形と実験方法が異なる 2 種類の実験を行う。考察の際に使用 した先行研究 ${ }^{4)}$ の波形（波形パターン A， B，Dおよび E）も含め本 実験で用いた元波形を図 2 に示す。また, 本実験で使用した元波形 の FFT 分析結果による卓越振動数と加速度振幅比を表 1 にまとめ た。ここには各波形パターンでもっとも卓越した振動数の振幅に対 して 8 割以上の振幅をもつ卓越振動数をすべて記した。

入力振動の作成にあたっては, 図 2 の元波形の時間間隔を増減し, 卓越振動数を変化させる。そのため, 同じ元波形でも卓越振動数に よって継続時間が変化する。さらに先行研究 7)他の実験範囲に基づき それぞれの実験の加速度最大值を定めた。これらの条件から目標波 形を忠実に再現できる本学の振動制御装置を用いて入力振動を作成 した。実験 A,Bで対象とした振動条件をそれぞれ表 2,3 に示した。

各回の実験では, 先行研究 7) で用いた実験方法と整合させるため, 最初に基準とする $0.63 \mathrm{~Hz} \cdot 25 \mathrm{~cm} / \mathrm{sec}^{2}$ の正弦振動を 15 秒〜 30 秒間 入力する。振動を 10 秒間停止した後, 任意のパターンで卓越振動 数を 1 種類に固定し, 加速度最大值が段階的に大きくなるよう, 各 10 秒の間をあけてランダム振動を連続して入力する。

被験者は振動を感じている間ボタンを押し続ける。被験者の知覚 応答はボタンへの反応に基づいて評価し, 評価対象とする振動の継 続時間内に一定時間ボタンを断続的に押し続けた被験者を, 対象の 振動を知覚したものとみなした。

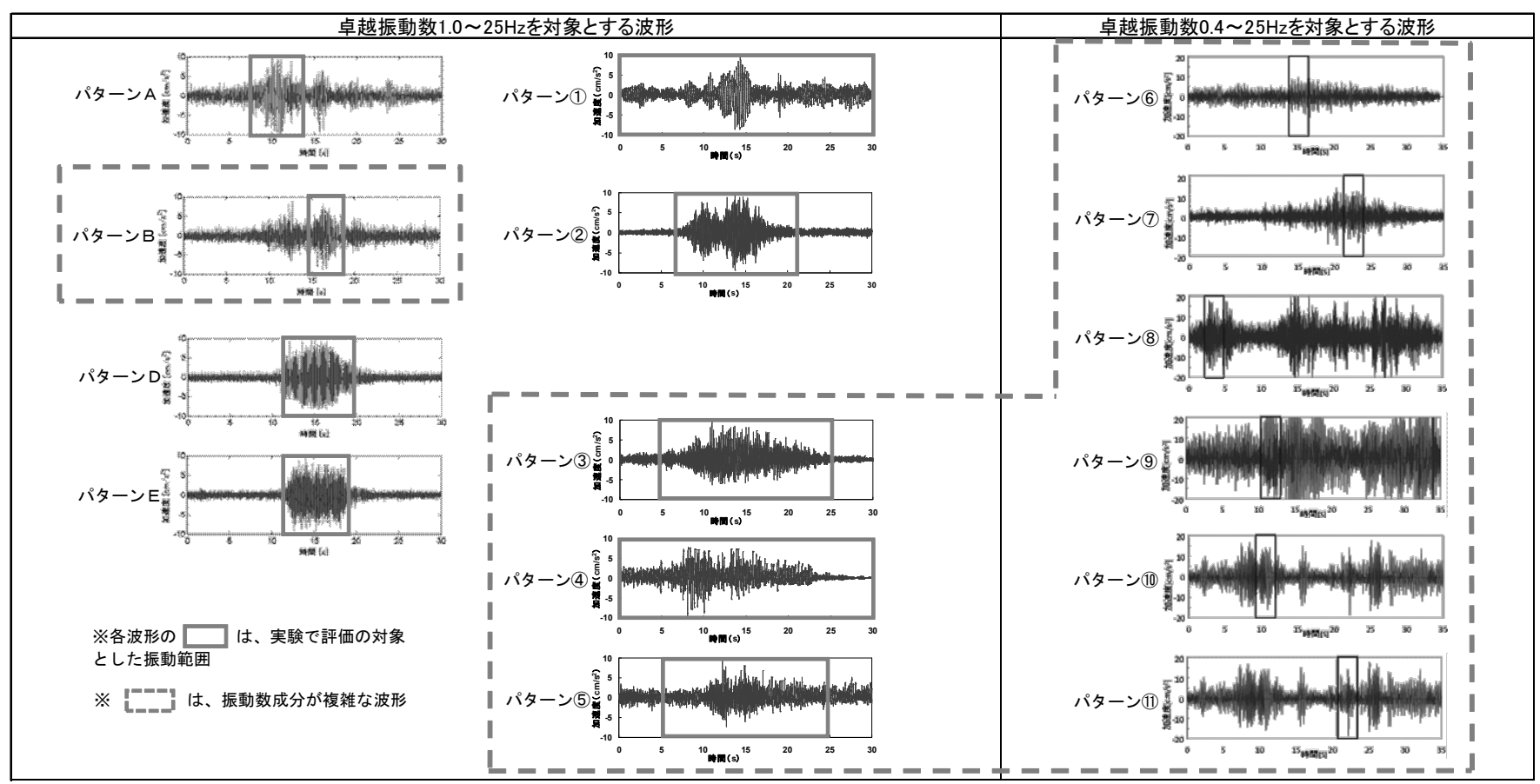

図 2 先行研究 ${ }^{4)}$ の波形も含め本実験で用いた元波形 
表 1 元波形の FFT 分析による卓越振動数と振幅比一覧

\begin{tabular}{|c|c|c|c|c|c|c|c|c|}
\hline 実 & \multirow{2}{*}{ 波形パターン } & \multirow{2}{*}{ 加振源 } & \multicolumn{3}{|c|}{ 卓越振動数 $(\mathrm{Hz})$} & \multicolumn{3}{|c|}{ 振幅比 } \\
\hline 験 & & & 第1 & 第2 & 第3 & 第1 & 第2 & 第3 \\
\hline \multirow{5}{*}{$\begin{array}{c}\text { 実 } \\
\text { 験 } \\
\text { A }\end{array}$} & パターン (1) & 道路交通 & 3.906 & & & 1 & & \\
\hline & パターン(2) & 鉄道交通 & 10.74 & & & 1 & & \\
\hline & パターン(3) & 鉄道交通 & 6.348 & 17.58 & & 1 & 0.828 & \\
\hline & パターン(4) & 鉄道交通 & 4.883 & 9.766 & & 0.972 & 1 & \\
\hline & パターン(5) & 鉄道交通 & 13.18 & 20.51 & & 1 & 0.927 & \\
\hline \multirow{6}{*}{$\begin{array}{c}\text { 実 } \\
\text { 験 } \\
\text { B }\end{array}$} & パターン6 & 鉄道交通 & 7.813 & 5.469 & & 1 & 0.841 & \\
\hline & パターン (7) & 道路交通 & 11.33 & 8.594 & 6.641 & 1 & 0.999 & 0.990 \\
\hline & パターン 8 & 道路交通 & 15.63 & 12.11 & & 1 & 0.951 & \\
\hline & パターン9 & 建設工事 & 12.11 & 6.250 & & 1 & 0.974 & \\
\hline & パターン (10 & 建設工事 & 5.078 & 8.203 & & 1 & 0.818 & \\
\hline & パターン(11) & 建設工事 & 5.078 & 8.203 & & 1 & 0.901 & \\
\hline
\end{tabular}

※ 卓越振動数は最も大きい第 1 卓越振動数の振幅と比し8割以上の振幅をもつ振動数を示す

表 2 実験 Aで入力した振動の条件

\begin{tabular}{|c|c|c|c|c|c|c|c|c|}
\hline & \multicolumn{6}{|c|}{ 加速度最大值 $\left(\mathrm{cm} / \mathrm{sec}^{2}\right)$} & \multirow{2}{*}{$\begin{array}{c}\text { 継続時間45秒に } \\
\text { 入力範囲を限定した } \\
\text { 波形ハハターン }\end{array}$} \\
\hline & & 1.6 & 4 & 10 & 25 & 63 & 160 & \\
\hline \multirow{5}{*}{$\begin{array}{l}\text { 卓 } \\
\text { 越 } \\
\text { 振 } \\
\text { 動 } \\
\text { 数 }\end{array}$} & $1.0 \mathrm{~Hz}$ & $\bullet$ & $\bullet$ & O & O & O & $\mathrm{O}$ & $\begin{array}{l}\text { パターン } \\
\text { (1), (2) (3), (4), (5) }\end{array}$ \\
\hline & $2.5 \mathrm{~Hz}$ & $\bullet$ & - & 0 & 0 & 0 & 0 & (1) \\
\hline & $4.0 \mathrm{~Hz}$ & $\bullet$ & $\bullet$ & O & O & O & & パターン(4), (5) \\
\hline & $10 \mathrm{~Hz}$ & $\bullet$ & • & $\bullet$ & 0 & 0 & & - \\
\hline & $25 \mathrm{~Hz}$ & • & • & • & • & 0 & & - \\
\hline
\end{tabular}

表 3 実験 B で入力した振動の条件

\begin{tabular}{|c|c|c|c|c|c|c|}
\hline & \multicolumn{5}{|c|}{ 加速度最大値 $\left(\mathrm{cm} / \mathrm{sec}^{2}\right)$} \\
\hline & & 1.6 & 4 & 10 & 25 & 63 \\
\hline \multirow{6}{*}{ 卓 } & $0.4 \mathrm{~Hz}$ & - & 0 & 0 & 0 & 0 \\
\hline & $1.0 \mathrm{~Hz}$ & 0 & 0 & 0 & 0 & 0 \\
\hline & $2.5 \mathrm{~Hz}$ & 0 & 0 & 0 & 0 & 0 \\
\hline & $4.0 \mathrm{~Hz}$ & ○ & 0 & 0 & 0 & 0 \\
\hline & $10 \mathrm{~Hz}$ & 0 & 0 & 0 & 0 & 0 \\
\hline & $25 \mathrm{~Hz}$ & 0 & 0 & 0 & 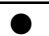 & 0 \\
\hline
\end{tabular}

先行研究との比較のために, 被験者は $18 \sim 22$ 歳の女性とし, 実 験 $\mathrm{A}, \mathrm{B}$ それぞれ 5 日間で 40 人 (実験 B のみ 1 名被験者交代あり) 実施した。

\section{(2) 実験 Aの入力振動}

実験 A では, 図 2 に示す元波形パターン(1)〜(5)の 5 種類を対象と した。パターン(1が道路交通通過時, それ以外は鉄道通過時による 実測波形である。パターン(1)(2)単一の振動数成分が卓越している が, パターン (3)(4)(5) は, 複数の振動数の卓越がみられる波形である。 表 2 に示すように目標とする卓越振動数と加速度最大值を設定した。

入力振動の作成にあたっては, 各波形の加速度最大值の前後を中 心に, 図 2 の $\square$ で囲った範囲を評価の対象とする波形とした。卓 越振動数 $1.0 \mathrm{~Hz} ， 2.5 \mathrm{~Hz}$ では元波形によってこの範囲の継続時間が 45 秒を超える場合がある。そのため, 表 2 に示した元波形と卓越振 動数の組み合わせでは, 継続時間が 45 秒となるように入力振動を 作成した。卓越振動数が高く, 対象の範囲で継続時間が 45 秒を超 えない場合には, その前後に適宜範囲を広げ, いずれの入力振動も 5〜45 秒程度の継続時間となるようにした。表 2 の振動数と加速度 最大值をもつ正弦振動の実験も並行して行ったが, 継続時間は各振 動数とも 30 秒とした。

\section{（3）実験 B の入力振動}

実験 Bでは, 図 2 に示すパターン (6)〜11)の 6 種類を元波形とした。 パターン(6)は鉄道通過時, (7)8は道路交通通過時, (9)〜111は建設工 事時の実測振動である。表 3 に示すように目標とする卓越振動数と 加速度最大值を設定した。

入力振動の作成にあたっては, 各波形の加速度最大值の前後を中 心に, 図 2 に $\square$ で囲った範囲を評価の対象とする波形として定めた。 実験 B で用いた元波形は, いずれも振動数成分が複雑に複合する波 形を選択している。元波形とした実測振動の FFT 分析では，それぞ れ表 1 に示寸振動数が卓越している。実験ではこのうち, もっとも 振幅が大きい第 1 の卓越振動数が目標值となるように設定した。

入力振動作成後の FFT 分析の結果, どの波形にも目標值以外に卓 越する振動数成分がみられ, 第 2 , 第 3 の卓越振動数との関係を再 現していることが確認できた。そこで先行研究の結果 5)をふまえ， 卓越振動数は最大振幅の第 1 の卓越振動数である入力目標值を用い て評価することとした。一方, 加速度最大值は入力目標值に対する 再現性が $10 \%$ を超える場合もあるため, 各実験日の加速度最大值 の実測值を用いて評価することとした。

実験では, これらのランダム振動 36 種類（元波形 6 種類・卓越 振動数 6 種類）に加えて, 同表の振動数と加速度最大值を目標值と する正弦振動 6 種類（継続時間 15 秒）を入力した。振動の入力順 序は, 元波形のパターン, 卓越振動数ともランダムに設定し, 全日 共通の順序とした。

\section{3. 波形ごとにみるランダム振動の知覚}

(1) 実験 Aにおけるランダム振動の知覚

先行研究 4) と同様に, 振動数の代表值として FFT 分析による卓越 振動数を用い, 加速度の代表值として評価対象とした振動継続時間 内における加速度最大值を用いて, 実験 $\mathrm{A} て ゙$ 対象とした各波形の知 覚確率を評価したのが図 3 〜図 7 である。

各波形に対する知覚人数を評価し, 卓越振動数ごとに加速度最大 值間を直線補間して $10 ， 30 ， 50 ， 70 ， 90 \%$ の知覚確率に相当する 加速度を算出してプロットした。図中には加速度を目的変数, 卓越 振動数を説明変数（いずれも常用対数值）とした 2 次式による評価 曲線（知覚確率曲線）を示した。

単一の振動数が比較的顕著に卓越するパターン (1) と (2)では, 知覚 確率 $10 \%$ を評価できない振動数範囲があるものの, 知覚確率によら ず評価曲線は同様の形状を示しており，安定した傾向がみられる。

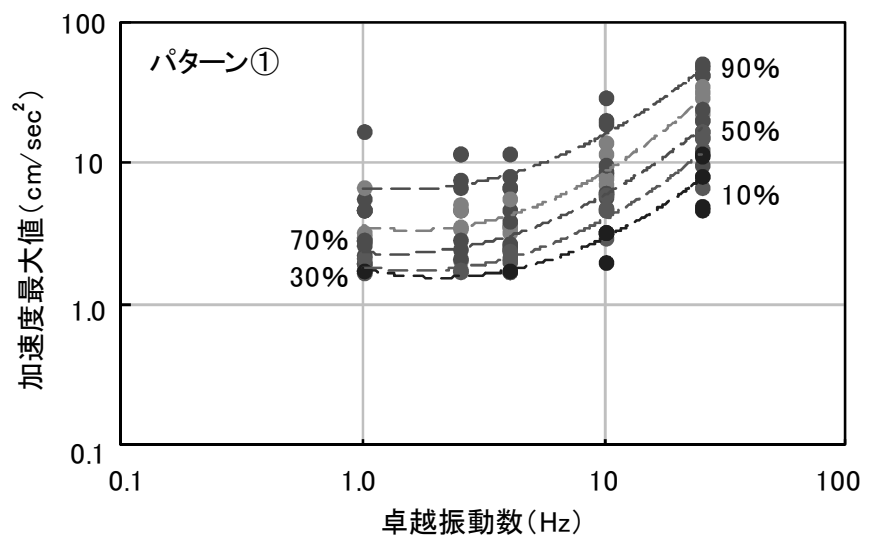

図 3 パターン(1) 対する知覚確率曲線 


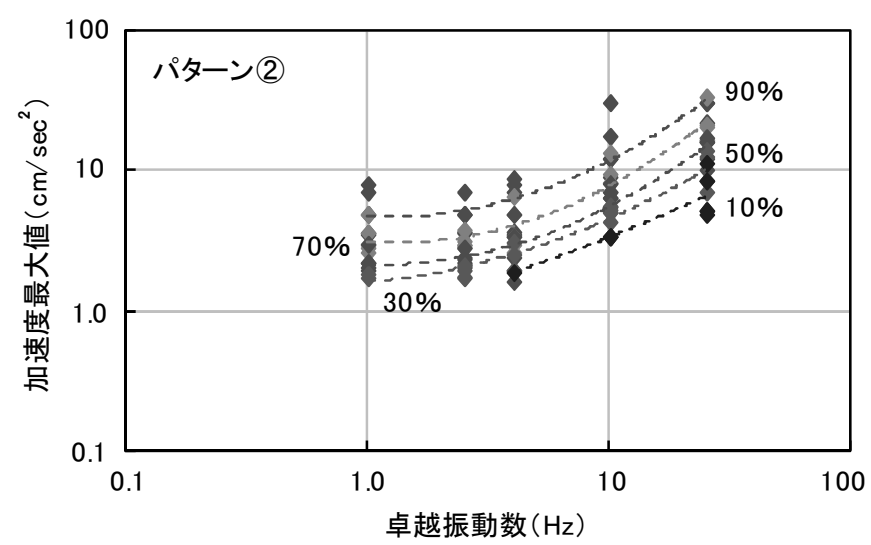

図4 パターン(2)に対する知覚確率曲線

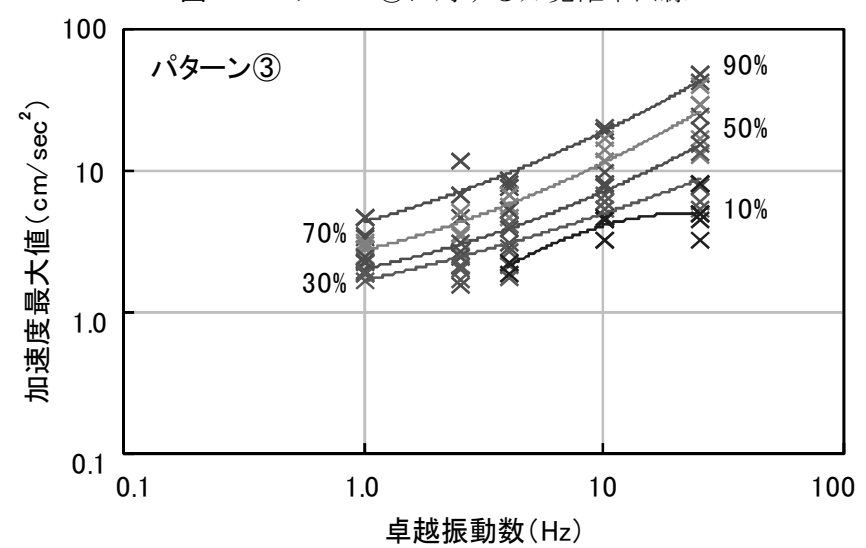

図 5 パターン(3)に対する知覚確率曲線

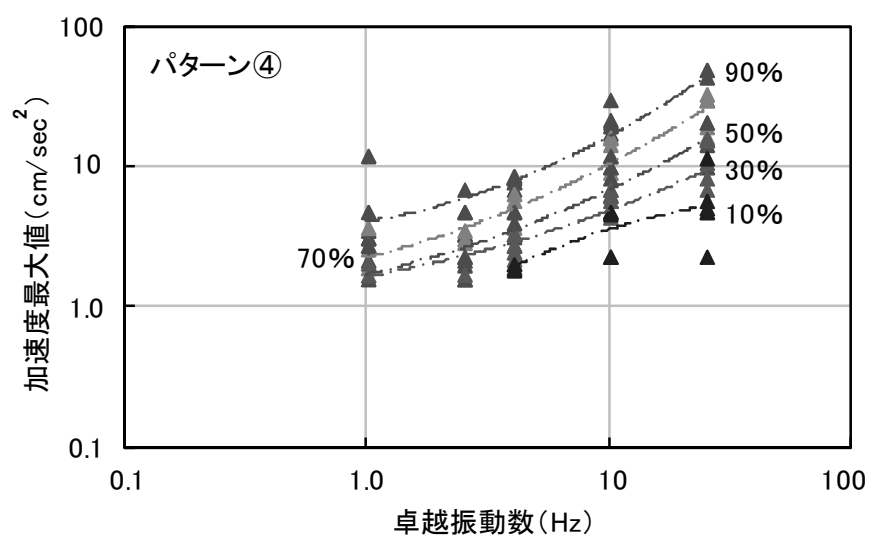

図 6 パターン(4)に対する知覚確率曲線

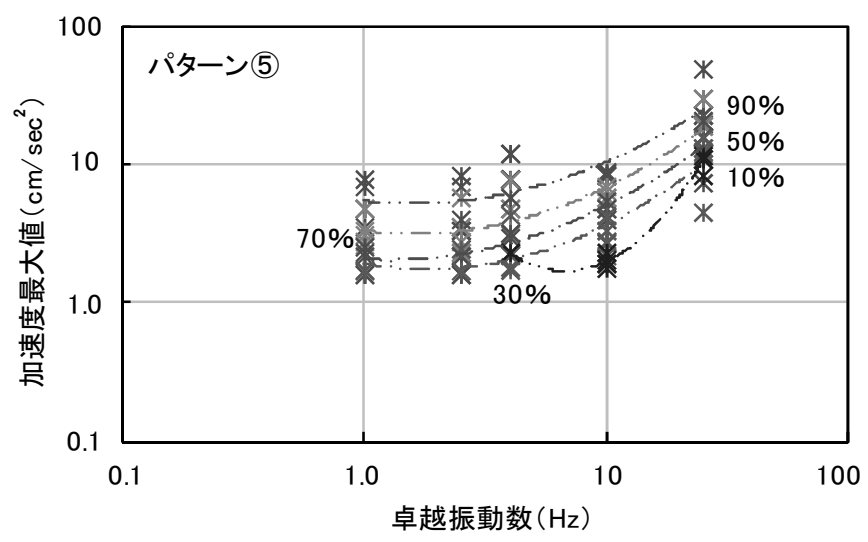

図 7 パターン(5)に対する知覚確率曲線
振動数成分が比較的複雑なパターン (3)(4)(5)では，知覚確率によっ て曲線の傾向に違いがある場合や卓越振動数によるばらつきもみら れる。広い範囲の振動数成分が含まれるパターン(5)，知覚確率が 低い範囲でばらつきが大きい結果となった。

これらをふまえて, 実験 $\mathrm{A}$ で対象とした波形ごとの知覚確率曲線 を比較したものが図 8 である。全体をみると, 波形の違いによらず, もっとも卓越する振動数と時系列波形における加速度最大值で評価 した場合，全波形の知覚確率曲線はほぼ同様な形状を示している。

知覚確率 $50 \%$ では波形ごとの違いも小さく, 平均的な代表值で評 価する場合には特に, 波形形状の違いによる知覚への影響はそれほ ど大きくないことがわかる。

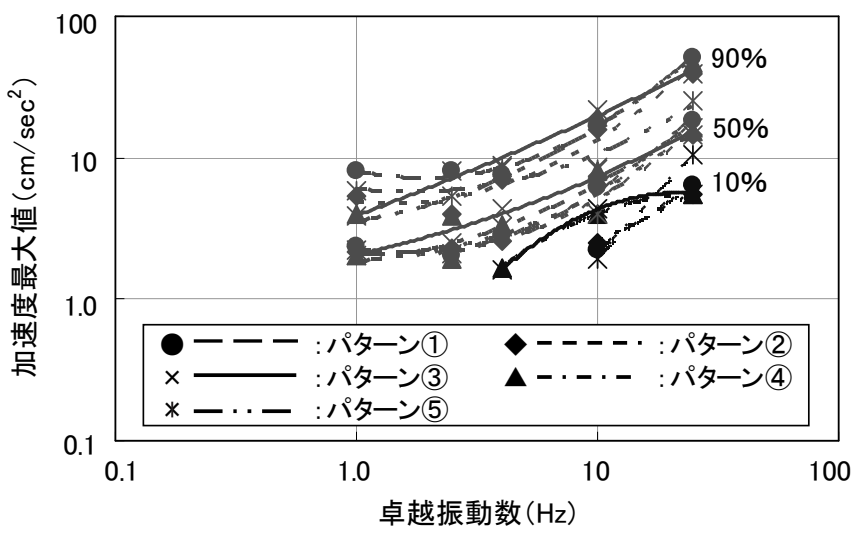

図 8 実験 $\mathrm{A}$ における知覚確率の比較

(2) 実験 B におけるランダム振動の知覚

実験 B で対象とした各波形の知覚確率を図 9 〜図 14 に示す。評 価に用いた物理量やそれぞれの知覚確率に相当する加速度の算出方 法は，実験 A と同様である。

卓越振動数や波形にかかわらず, 知覚確率曲線は同様な形状を示 す。そのなかで 3 つの卓越振動数成分が同程度に含まれるパターン (7)は, 被験者個々の知覚のばらつきが大きくなる特徵がある。一方, 第 2 の卓越成分の振動数が第 1 の卓越成分の振動数の約 2 倍となっ ているパターン(9)では, いずれの卓越振動数においても，個々の知 覚のばらつきが比較的安定しているのが特徴である。

一方，対象とした波形のうち，パターン(10およびパターン(11) 第 1 の卓越成分の振動数より, 第 2 の卓越成分の振動数が高くなっ

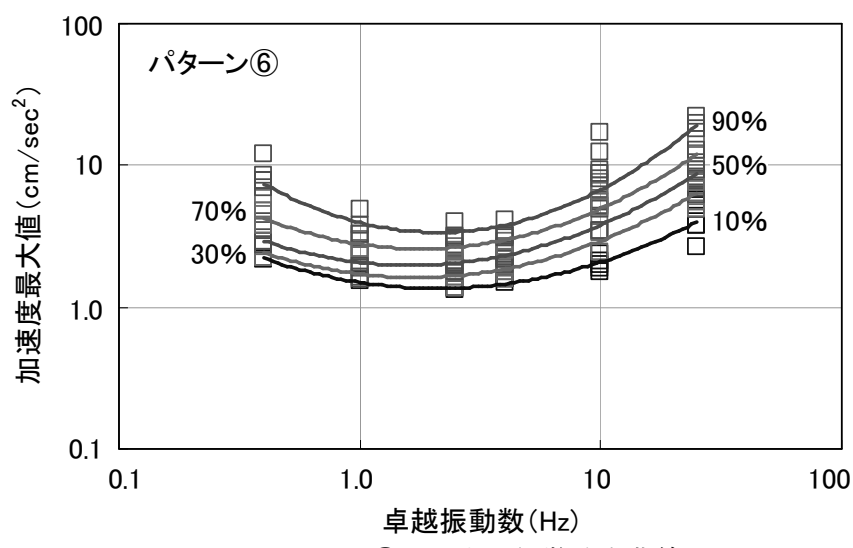

図 9 パターン66対する知覚確率曲線 


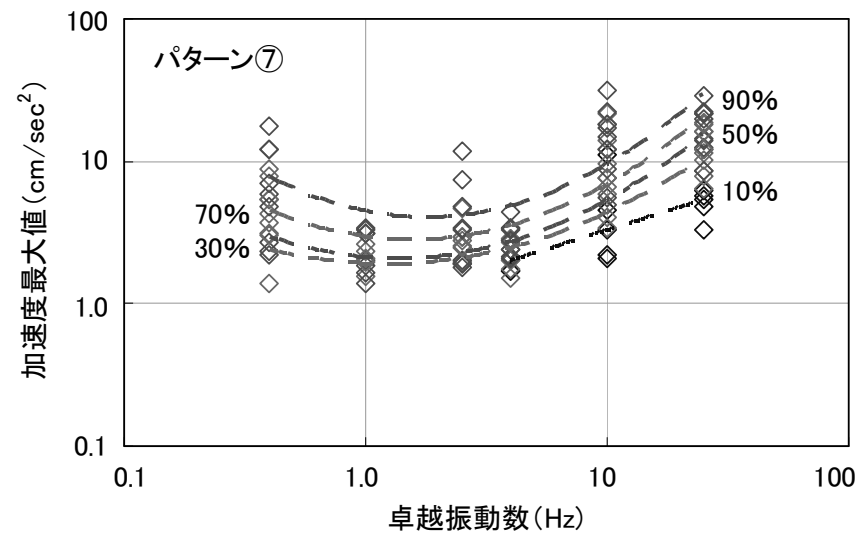

図 10 パターン(7)に対する知覚確率曲線

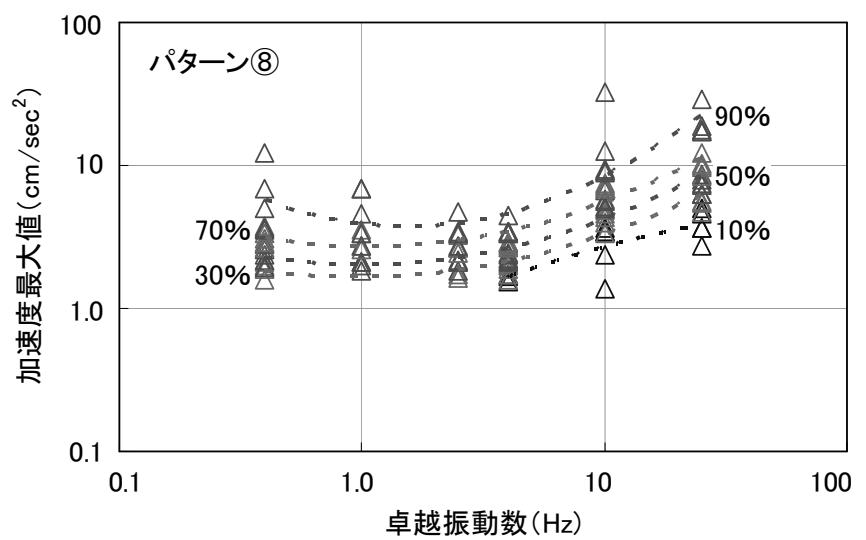

図 11 パターン8に対する知覚確率曲線

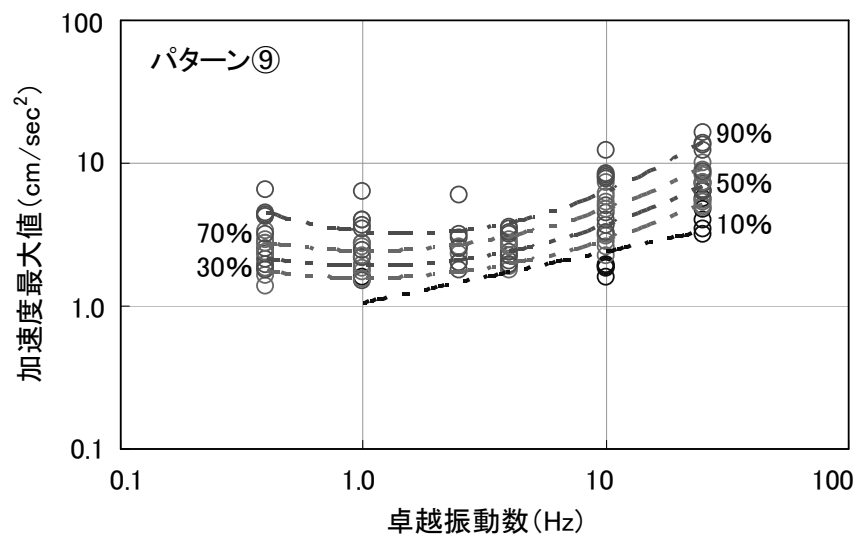

図 12 パターン9に対する知覚確率曲線

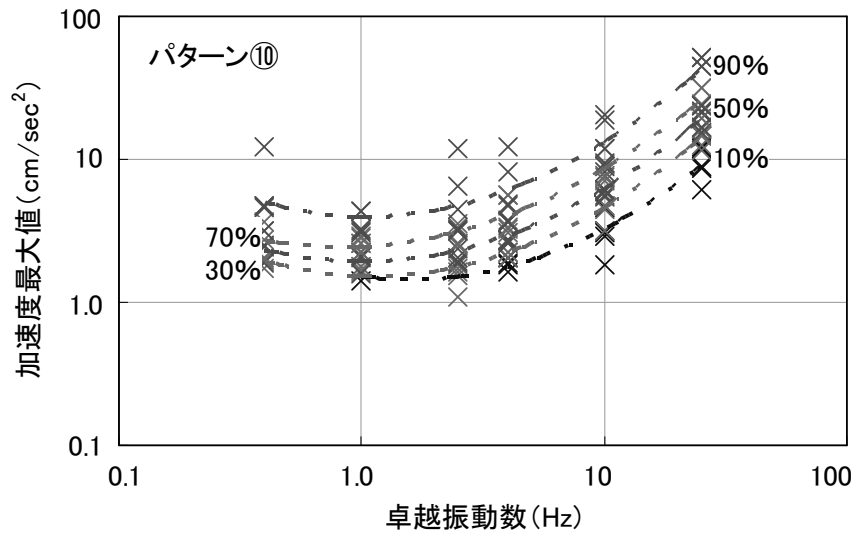

図 13 パターン10に対する知覚確率曲線

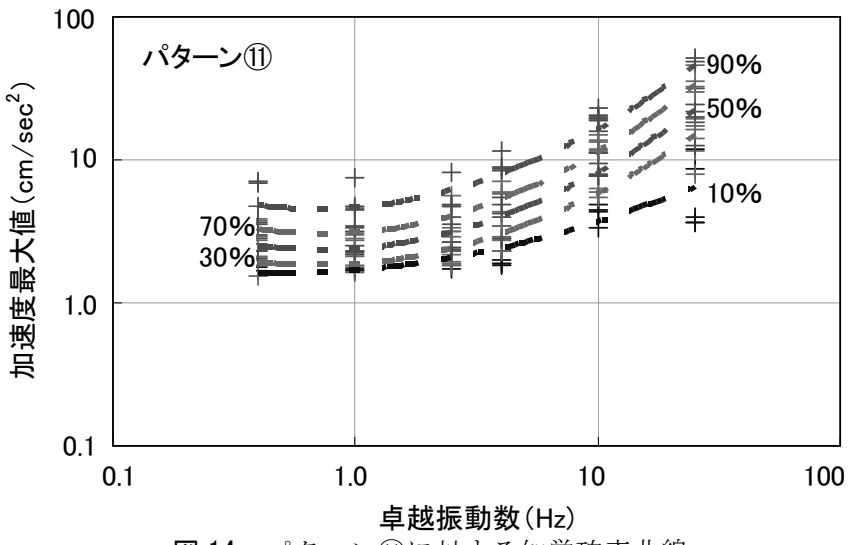

図 14 パターン11に対する知覚確率曲線

ている波形である。これらの場合, 卓越振動数が $0.4 \mathrm{~Hz}$ と低いと第 2 の振動数成分の影響をうけ，他の波形と比較して知覚確率がやや 高くなる特徵がある。

実験 B の結果から，10\%，50\%，90\%の知覚確率曲線を波形ご とに比較したものが図 15 である。同じ知覚確率曲線には, 波形の 種類によって概祆加速度振幅に 10～20\%の幅がある。一方，同じ波 形で卓越振動数が異なる場合, 知覚確率には 40\% 90\%近い差が生 じる。実験 B で対象とした波形は振動数成分がより複雑であり, 波 形による知覚確率の違いが先行研究 4,5)の結果より大きいが, それ以 上に卓越振動数の違いがランダム振動の知覚に及ぼす影響が大きい ことを示唆している。

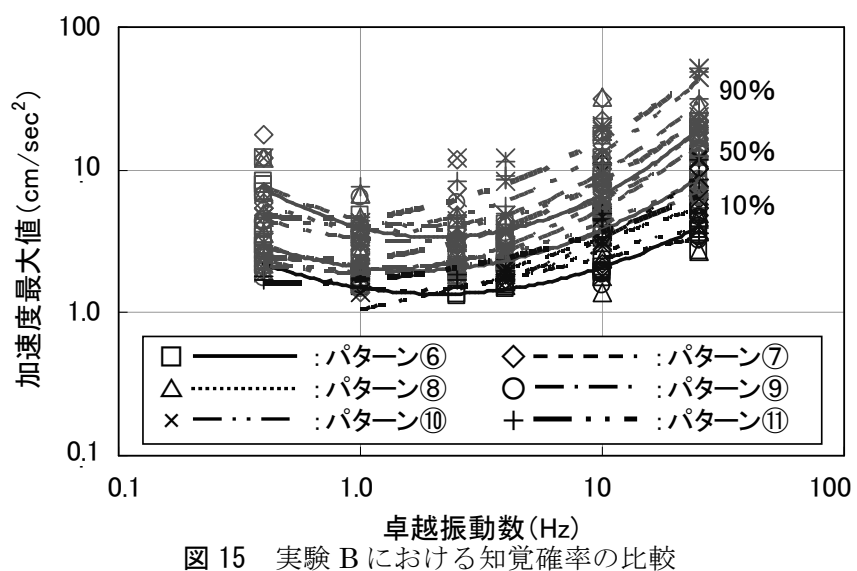

\section{4. ランダム振動の知覚に関する考察}

先行研究 4)で述べたように, ランダム振動の同じ波形の知覚確率 に対して，振動の入力方法や被験者の違いが及ぼす影響は小さい。 そのため, これらの実験結果の比較から，各実験で対象とした波形 の特徵が知覚確率に及ぼす影響を検証することが可能である。

先行研究 ${ }^{4)} 5$ 種類の波形および本論文の実験 Aで対象としたパ ターン(1)〜(5)と比較して, 実験 B で対象としたパターン(6)〜 (11)は, 複数の振動数が同程度に卓越するなど, より複雑な振動数成分をも つことが特徴である。3 種類の実験結果を比較したものが図 16 で ある。

図中に示す $20 \%$ ごとに算出した知覚確率を 2 次曲線で近似した 評価曲線で比較すると，30\%ではほぼ曲線が重なり，50\%の知覚確 率曲線もほぼ等しい加速度にある。知覚確率 10\%や 90\%では, 実 


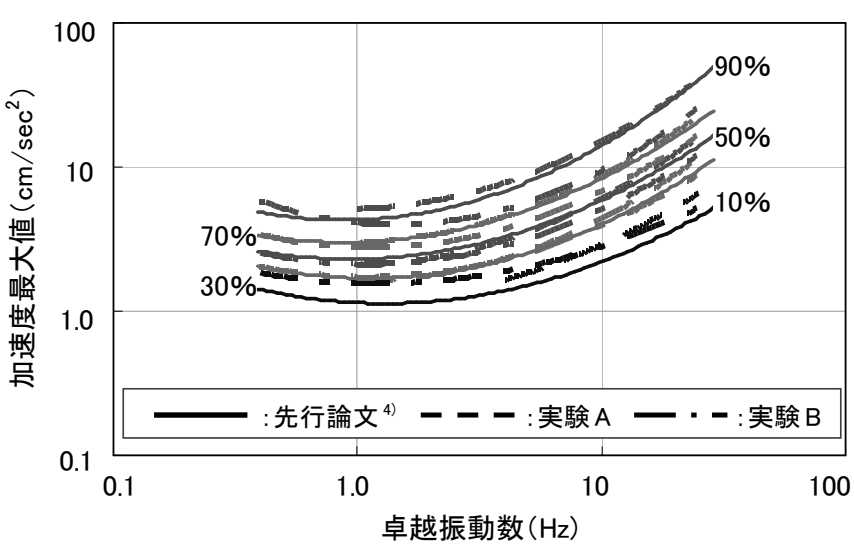

図 16 ランダム振動の知覚確率の比較

験による違いがより大きくなる傾向にある。

一方, ランダム振動と同じ振動数を設定した正弦振動に対して, 本実験と先行研究 4) の知覚確率を重辇きしたのが図 17 である。 正弦振動の場合, いずれの知覚確率曲線も概ね重なっており, 実験 による結果の違いはほとんどない。よって, 実験全体として被験者 の個人差に起因する知覚確率の違いはほとんどないことがわかる。

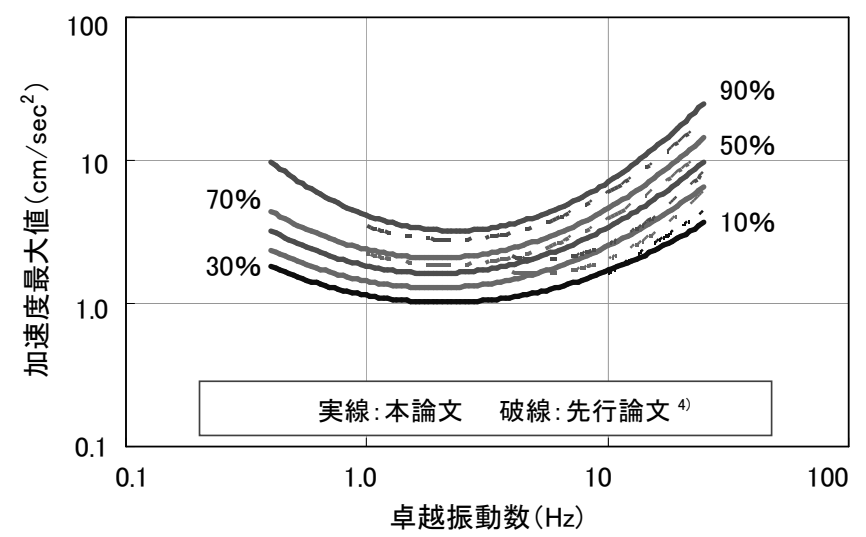

図 17 先行研究 4) と本論文における正弦振動の知覚確率の比較

このようにランダム振動と正弦振動に対する実験結果の比較から， 正弦振動と比較してランダム振動の場合には, 知覚確率のばらつき が大きい。正弦振動の実験結果の比較による個人差のばらつきが小 さいことをふまえると, ランダム振動の知覚確率曲線に生じるばら つきは, 波形形状や振動数特性など, ランダム振動の物理的な特性 の違いによるばらつきと考えることができる。

このようなランダム振動の波形の違いが知覚に及ぼす影響に関す る検討として, 先行研究 ${ }^{4}$ および本論文で対象とした 16 種類のラン ダム振動の波形を比較すると, 知覚確率 30\%〜 70\%の範囲では波形 による加速度振幅のばらつきは小さいが，知覚確率 $10 \%$ と $90 \%$ で は, 図 18 にみるように波形によるばらつきが大きくなる。知覚確 率 10\%および $90 \%$ の場合, 最大加速度で $40 \%$ 程度の幅の中で知覚 確率がばらついている。

しかしながら, 同一波形における卓越振動数の違いに注目すると, 最大で $60 \%$ 程度の知覚確率の差が生じることから, ランダム振動の 知覚に対しては, 波形の違いより卓越振動数の違いが及ぼす影響の 方が大きいと言うことができる。

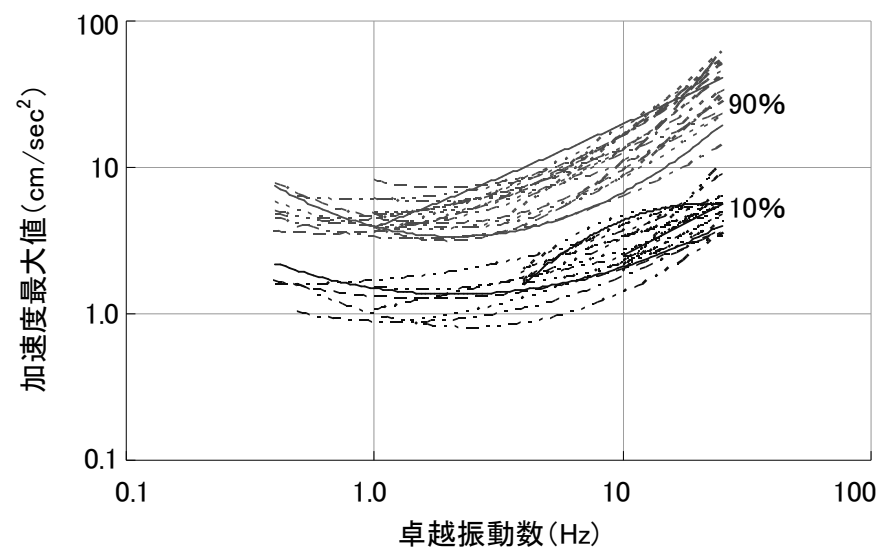

図 1816 種類のランダム振動の知覚確率 $10 \%$ と $90 \%$ 曲線の比較

以上の考察をふまえ, 本研究で対象とした戸建て住宅で実測され た元波形に基づく 16 種類の波形による被験者実験の結果を統合し て, ランダム振動の知覚確率として評価したものが図 19 である。 正弦振動の結果も付記した。ランダム振動の知覚確率曲線は同様の 形状の曲線が加速度に対してほぼ等間隔に並び, 安定した特性を示 している。この結果からも, FFT 分析によるもっとも卓越する振動 数と時系列波形における加速度最大值を用いることで, ランダム振 動の知覚確率を概吝評価できることがわかる。ただし，前述したよ うに, 知覚確率 $10 \%$ や $90 \%$ などで評価する場合には, 波形による ばらつきの影響があることを考慮する必要がある。

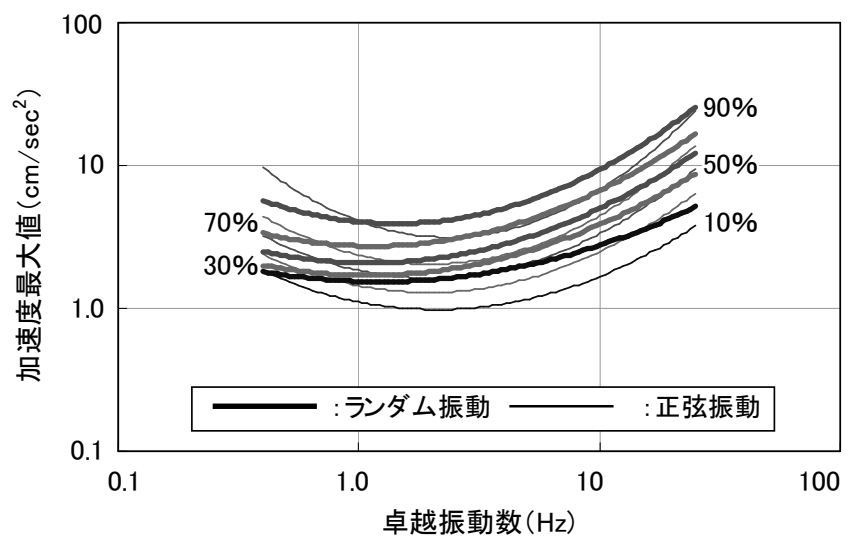

図 1916 種類の波形を統合したランダム振動の知覚確率の評価

また, 正弦振動との比較では, 正弦振動の知覚確率曲線の方が全 体的に加速度の低い範囲にあり, ランダム振動の方が概ね振動を知 覚しにくい傾向にある。一方, ランダム振動と正弦振動に対する知 覚確率曲線の形状はやや異なり, 振動数によって両者の知覚確率の 差に違いがみられる。

先行研究 ${ }^{4)}$ と比較しても, 正弦振動とランダム振動に関する知覚 確率の違いがやや大きい傾向にある。特に低振動数範囲で知覚確率 の大小関係が逆転する範囲があることを考慮すると, ランダム振動 の振動数成分の特徴によって, もっとも卓越する振動数以外の振動 数成分が, ランダム振動の知覚確率に影響を及ぼすことが示唆され る。

ランダム振動と正弦振動との知覚確率の差は概ね加速度振幅とし 
て 20〜 40\%程度であるが, 振動数範囲によって変動する。特に, 正 弦振動を敏感に知覚する $1.5 \sim 2.5 \mathrm{~Hz}$ の方が両者の差が開く傾向に ある。

\section{5. おわりに}

本研究は, ランダム振動の振動数特性が知覚確率に及ぼす影響を 明らかにする目的で, 戸建て住宅における実測振動を元波形として, 卓越振動数と加速度最大值を変化させた被験者実験を行った。本研 究で得られた知見を以下にまとめる。

1) 本論文では, 振動数成分の特徵が異なる 16 種類のランダム振 動を対象とし, 振動数特性によって生じる知覚確率の違いなど の評価特性を明らかにした。その結果, 平均的な知覚確率 $50 \%$ 前後を対象とすることで, FFT 分析による卓越振動数と加速度 最大值を用いたランダム振動の知覚評価の可能性を見いだすこ とができた。これらは, 環境振動の性能設計実務におけるラン ダム振動評価に対する有用な知見と考えられる。

2 ) 複数の振動数が同程度に卓越するなど, 複合的な振動数成分を もつ波形に関しては, 卓越する振動数も程度差や振動数の開き など，それぞれの特徴によって，第 2 ，第 3 の振幅をもつ振動 数成分が知覚に影響を及ぼす可能性を見いだした。

3 ） ランダム振動の波形の違いによる知覚確率のばらつきは，知覚 確率 30〜 50\%程度では比較的小さく, 10\%や 90\%の知覚確率 で大きくなる。これをふまえると，より厳しい知覚確率 $10 \%$ な じを基準に評価しようとする場合，波形による振動数特性の違 いを考慮する必要がある。
4 ）ランダム振動と正弦振動における知覚確率を比較した結果，全 体としてランダム振動の方が感じにくい傾向にある。卓越する 振動数によって異なるが, 両者の差は加速度振幅として概ね 20 〜 40\%程度である。特に, 正弦振動を鋭敏に知覚する振動数範 囲，1.5 2.5 Hz 程度で，両者の差が開く傾向にある。

本実験では多くの被験者の協力を得た。記して謝意を表する。

\section{参考文献}

1) ISO 2631-1 : Mechanical vibration and shock - Evaluation of human exposure to whole-body vibration - Part 1, General requirements, 1997.

2）日本建築学会：建築物の振動に関する居住性能評価指針・同解説，第 2 版, 2004.5

3）塩谷清人, 藤井邦雄, 田村幸雄, 神田順 : 2 次元水平ランダム振動の知 覚閾に関する研究, 日本建築学会構造系論文集, 第 485 号, pp.35-42, 1996.7

4）石川孝重，国松直：交通による戸建て住宅の水平方向の実測波形を用い たランダム振動に対する環境振動評価, 日本建築学会環境系論文集, 第 76 巻，第 667 号，pp.761-766，2011.9

5) 石川孝重 他：ランダム振動に対する振動感覚の評価に向けて(その 17) （その 21), 日本建築学会大会学術講演梗概集, 環境工学 I , pp.397-406, 2011.8

6) 石川孝重 他：ランダム振動に対する振動感覚の評価に向けて(その 22) （その 24), 日本建築学会大会学術講演梗概集, 環境工学 I , pp.361 $\sim 366,2012.9$

7）野田千津子, 石川孝重 : 水平振動を受ける被験者の状況が知覚閾に及ぼ 寸影響, 日本建築学会計画系論文集, 第 524 号, pp.9-14, 1999.10

（2013年 7 月 9 日原稿受理，2014年 1 月23日採用決定） 